\author{
JoANNA PIECZYŃSKA, KAROLINA ŁAGOWSKA
}

Wydział Nauk o Żywności i Żywieniu Uniwersytet Przyrodniczy w Poznaniu Wojska Polskiego 31, 60-624 Poznan E-mail: joanna.pieczynska@onet.eu karolina.lagowska@up.poznan.pl

\title{
RZADKIE CHOROBY METABOLICZNE - CHARAKTERYSTYKA I DIETOTERAPIA
}

\section{WSTEP}

Wrodzone błędy metabolizmu (ang. inborn errors of metabolism, IEM) to grupa uwarunkowanych genetycznie chorób, do których zalicza się przede wszystkim fenyloketonurię, galaktozemię i choroby spichrzeniowe glikogenu. Pierwszy raz termin ten został użyty na poczatku XX w., przez angielskiego lekarza Archibalda Garroda, specjalistę w dziedzinie genetyki molekularnej. W 1902 r. opublikował on wykład pt. „Inborn errors of metabolism" (GARROD i wspólaut. 1902), w którym poruszał temat alkaptonurii, cystynurii, pentozurii oraz albinizmu i wyjaśnił mechanizm ich dziedziczenia, patogenezę i etiologię (patrz ARGMANN i współaut. 2016). Choroby te dziedziczone sa w sposób autosomalny recesywny, co oznacza, iż nie sa sprzężone $z$ chromosomami płci $i$ ujawniaja się tylko u osobników homozygotycznych. Podłoże biochemiczne każdej $z$ jednostek chorobowych będacych w grupie IEM jest podobne i polega na upośledzeniu szlaku metabolicznego. Wynika to $z \mathrm{mu}-$ tacji w obrębie genu, który koduje enzym umożliwiający przekształcenie substratów w produkty. Następstwem tego jest obniżona zdolność organizmu do syntetyzowania niezbędnych związków, m.in. aminokwasów, lub akumulacja substancji, które w nadmiarze moga przejawiać działanie toksyczne lub zakłócać prawidłowe funkcjonowanie organizmu (El-Hattab i Reid SutTon 2012). Może dochodzić też do nadprodukcji, zaburzeń transportu $\mathrm{w}$ organizmie lub utraty funkcji receptorowych. Ogólna częstość występowa- nia tych chorób to 1:2500 żywych urodzeń (JEANMONOD i współaut. 2020). Większość $z$ nich diagnozowana jest $\mathrm{w}$ trakcie badań przesiewowych noworodków. W Polsce wykonywane sa obowiazkowo na mocy Rozporzadzenia Ministra Zdrowia „w sprawie zakresu świadczeń opieki zdrowotnej, w tym badań przesiewowych oraz okresów, w których te badania sa przeprowadzane" (Dz.U. $2004 \mathrm{nr}$ 276 poz. 2740). Badany nie ponosi żadnych zwiazanych $z$ tym kosztów. Pozwala to na wczesne wykrycie choroby i natychmiastowe wdrożenie leczenia, w tym przede wszystkim dietoterapii.

Oprócz badań przesiewowych, wykonuje się również badania biochemiczne wykrywajace specyficzne metabolity we krwi lub moczu. Analizuje się również korelację między genotypem a fenotypem chorego, by rozpoznać rodzaj mutacji i ocenić jej efekty. Istnieja również bardziej zaawansowane molekularne metody diagnostyczne, takie jak analiza DNA pacjenta (DAGLI i współaut. 2009a). Diagnoza wrodzonych błędów metabolizmu jest w znacznym stopniu utrudniona przez niespecyficzne objawy, które towarzyszą poszczególnym chorobom. Zwykle ujawniaja się one w ciagu kilku godzin do 2 dni po porodzie. Moga to być np. niewydolność oddechowa, hipotonia, słaby odruch ssania, wymioty czy apatia (EL-HATTAB i ReID SutTon 2012). Objawy te sa niespecyficzne, nie da się ich bezpośrednio przypisać do konkretnego zaburzenia i podobne do takich, które występuja przy innych, jak np. posocznica. Sa to choroby przewlekłe. Wdrożony proces farmako- i dietoterapii 
ma charakter objawowy. Do połowy XX w. jedyna metoda leczenia było wyeliminowanie $z$ diety tych produktów czy składników, które wywoływały objawy, np. w przypadku zaburzeń metabolizmu aminokwasów ograniczano podaż białka w pożywieniu (ARGMAN i współaut. 2016). Wraz z postępem medycyny możliwości terapii poszerzaja się o np. ingerencję $\mathrm{w}$ enzymy i takie ich zmodyfikowanie, by ich działanie było odpowiednie, podawanie substytucyjne enzymów czy przeszczepy nieprawidłowo funkcjonujących organów, które rozpoczna syntezę brakujacych enzymów. Duże nadzieje wiąże się także $z$ terapia genowa $\mathrm{w}$ leczeniu, np. mukowiscydozy czy hemofilii.

\section{FENYLOKETONURIA}

Częstość występowania fenyloketonurii $\mathrm{w}$ Polsce wynosi ok.1:7000 żywych urodzeń, w Europie 1:10000, a USA 1:15000 (YILDIZ i SIVRI 2019, ŻóŁKOWSKA i współaut. 2018). Diagnozowana jest ona na podstawie testu Guthriego(MAZURCZAK i współaut. 2000), który pozwala wykryć zbyt wysokie stężenie fenyloalaniny we krwi. Podstawa tej metody jest fakt, iż zawarta $\mathrm{w}$ pożywce $\beta$-2-tienyloamina hamuje wzrost bakterii $\mathrm{Ba}$ cillus subtilis (OŁTARZEWSKI 2018). W przypadku, gdy w naniesionej na pożywkę krwi, znajduje się wysokie stężenie fenyloalaniny, następuje wzrost bakterii, ponieważ aminokwas ten znosi działanie inhibitora, jakim jest $\beta$-2-tienyloamina. U większości chorych podłożem choroby jest mutacja w chromosomie 12. Warunkuje on aktywność hydroksylazy fenyloalaninowej, która syntetyzowana $\mathrm{w}$ watrobie, powoduje przekształcenie fenyloalaniny do tyrozyny. Tylko u nieznacznej grupy chorych przyczyna jest zaburzenie funkcji enzymów odpowiedzialnych za regeneracje lub powstawanie tetrahydrobiopteryny (BH4), która jest kofaktorem hydroksylazy fenyloalaninowej (PAH) (JAROCHOWICZ i MAZUR 2007). Skutkiem fenyloketonurii jest gromadzenie we krwi i plynach ustrojowych chorego nadmiernej ilości fenyloalaniny i jej metabolitów, przy jednoczesnym niedoborze tyrozyny. Wysokie stężenia fenyloalaniny, czyli stan hiperfenyloalaninemii, negatywnie koreluja $z$ rozwojem neurologicznym pacjenta, ze względu na nieodwracalne zmiany w ośrodkowym układzie nerwowym. Wynika to z niekorzystnego wpływu fenyloalaniny na transport innych aminokwasów przez błony komórkowe i barierę krew-mózg. Nie bez znaczenia jest również rola fenyloalaniny $\mathrm{w}$ stymulacji rozpadu mieliny $\mathrm{i}, \mathrm{w}$ zwiąk u $z$ tym, utraty znacznej liczby neuronów u chorych (CONCOLINo i współaut. 2017).
Zalecane stężenie fenyloalaniny we krwi chorego $z$ fenyloketonuria, jakie powinno być utrzymane przez całe życie, powinno mieścić się w przedziale 120-360 $\mu \mathrm{mol} / 1 \mathrm{krwi}(2-6$ $\mathrm{mg} / \mathrm{dl})$ (SingH i współaut. 2014). Kluczowy jest regularny monitoring tego stężenia (przynajmniej raz $\mathrm{w}$ miesiącu) i ewentualna modyfikacja diety $\mathrm{w}$ celu zapobiegania wartościom przekraczającym zakres referencyjny.

Szczególną ostrożność należy zachować w przypadku chorych, u których przeważaja procesy anaboliczne $\mathrm{w}$ organizmie, tj. kobiety ciężarne i dzieci, u których należy znacznie zwiększyć częstotliwość kontroli stężenia fenyloalaniny we krwi.

\section{LECZENIE DIETETYCZNE}

Leczenie fenyloketonurii opiera się głównie na wprowadzeniu, tzw. "diet for life", czyli diety $z$ koniecznościa stosowania przez całe życie. Podstawowym celem jest redukcja podwyższonego stężenia fenyloalaniny we krwi i utrzymanie jej w granicach indywidualnej tolerancji, co osiagane jest przez ograniczenie podaży białka ze źródeł konwencjonalnych. Produktami zabronionymi w diecie chorego sa przede wszystkim: mięso i jego przetwory, mleko i nabiał, warzywa straczkowe, przetwory zbożowe, czekolada i kakao, orzechy i nasiona, jaja oraz żywność słodzona aspartamem. Zalecana podaż białka pokrywa głównie przyjmowanie żywności specjalnego przeznaczenia, tj. preparatów medycznych zawierajacych białko pozbawione fenyloalaniny. Pozostała ilość białka jest dostarczana przez spożycie warzyw i owoców, a także żywności niskobiałkowej. Stopień ograniczenia podaży białka, a przez to fenyloalaniny, ze zwyczajowej żywności zależy od indywidualnej tolerancji pacjenta. Jest to ilość fenyloalaniny (w mg), która pacjent może przyjąc $z$ dobowa dietą bez negatywnego wpływu na zdrowie. Tolerancja jest określana po zdiagnozowaniu choroby, a następnie określana w wyznaczonych przez lekarza odstępach czasu, dostosowanych do etapów rozwoju dziecka.

$\mathrm{Na}$ rynku obecnie dostępne sa liczne produkty, które sa źródłem białka pozbawionego lub $z$ ograniczona ilościa fenyloalaniny, a dodatkowo uzupełniaja deficytowe witaminy i składniki mineralne. Warto zwrócić uwagę, iż alfa-aminokwasy $z$ tego rodzaju produktów ulegaja znacznie szybszemu wchłanianiu i utlenianiu niż zwykłe białka pokarmowe (PENA i współaut. 2015). Żywność medyczna stosuje się zamiast posiłku lub jako jego uzupełnienie, najczęściej ok. 3 razy na dobę. Istnieja doniesienia, że częstsze spożywanie niskofenyloalaninowych produktów $z$ codzienną dietą i przez to utrzy- 
manie niskich wartości fenyloalaniny we krwi, może w przeciagu kilku lat wpłynąć na podwyższenie wyjściowej tolerancji osobniczej chorego (SingH i współaut. 2014). Dodatkową korzyścią jest to, iż chorzy stosujący dietę bazująca na żywności medycznej, maja porównywalna do osób zdrowych gęstość kośćca. Natomiast, dzięki wzbogaceniu tych preparatów w składniki deficytowe, nie cierpia oni $z$ powodu niedoborów witaminy D (GEIGER i współaut. 2016).

Popularne staje się także wykorzystanie glikomakropeptydu, czyli białka serwatkowego, zawierajacego 2-5 mg fenyloalaniny/g białka. Stosuje się je do wzbogacania innych produktów, ponieważ dzięki temu zabiegowi można obniżyć u chorych stężenie hormonu pobudzajacego apetyt (greliny). Dodatkowo, zwiększony zostaje poziom sytości i wykorzystanie białka przez organizm (SINGH i współaut. 2014). Nie jest to jednak strategia żywieniowa odpowiednia dla wszystkich chorych, ze względu na wysoka cenę i obecny brak refundacji w Polsce.

Kolejna, alternatywna metoda leczenia dietetycznego sa aminokwasy obojętne o wielkiej cząsteczce (LNAAs). Dzięki LNAAs można zapewnić nawet do 30\% zapotrzebowania na białko w codziennej diecie. Pojawia się jednak znaczna trudność w monitorowaniu efektów leczenia $z$ wykorzystaniem doustnego podawania tych aminokwasów. Wynika to $z$ faktu, iż $\mathrm{w}$ trakcie stosowania terapii stężenie fenyloalaniny we krwi nadal pozostaje wysokie, natomiast jej stężenie w mózgu ulega obniżeniu. Kontrolowanie mózgowego stężenia fenyloalaniny jest trudne i niepraktyczne, dlatego nie jest to metoda często stosowana. Jest ona zalecana chorym, którzy $z$ różnych względów (np. upośledzenia umysłowego) nie radza sobie z dostosowaniem się do restrykcyjnej diety eliminacyjnej (Concolino i współaut. 2017). Nie jest to jednak sposób terapii zalecany dla dzieci i kobiet ciężarnych, ze względu na zbyt mała liczbę przeprowadzonych badań dotyczacych bezpieczeństwa stosowania, a przez to brak wiedzy o możliwych efektach ubocznych. Do tej pory wykazano, że suplementacja LNAAs, nawet bez stosowania diety ubogofenyloalalninowej, poprawia status monoamin mózgowych na zwierzęcych modelach PKU(myszy) (VAN VLIET i współaut. 2019). Biorac pod uwagę stopień odbudowy mózgowej serotoniny i noradrenaliny w dwóch grupach badanych: jednej, karmionej restrykcyjna dietę ubogofenyloalaninowa, oraz drugiej, spożywającej bardziej liberalna dietę $\mathrm{w}$ połaczeniu $\mathrm{Z}$ suplementacja LNAAs, udowodniono porównywalna efektywność obu metod (VAN VLIET i współaut. 2019).
Stosowana jest także sapropteryna (tetrahydrobiopteryna), farmaceutyczna forma kofaktora enzymu PAH, która podawana w dawkach terapeutycznych wpłynęła na istotny wzrost aktywności tego enzymu u pacjentów. U osób niestosujących odpowiedniej diety umożliwia ona obniżenie stężenia fenyloalaniny bez konieczności wprowadzania zmian w sposobie żywienia. Natomiast u osób, które stosuja dietę ubogofenyloalaninową, pomaga ograniczyć spożycie żywności medycznej, jak również pozwala na drobne odstepstwa w codziennej diecie. Jest to szczególnie istotne $\mathrm{w}$ odniesieniu do dzieci i młodzieży (BIK-MULTANOWSKI i PIETRZYK 2009).

Istnieje także terapia fenyloketonurii polegajaca na substytucji enzymatycznej, dostępna tylko dla chorych powyżej 16. roku życia. W formie podskórnych zastrzyków podawana jest liaza amoniakalna fenyloalaniny, enzym katalizujacy konwersję L-fenyloalaniny do amoniaku i kwasu trans-cytrynowego. Metoda ta nie jest jeszcze dostepna do rutynowego stosowania $\mathrm{w}$ szpitalach $\mathrm{i}$ placówkach medycznych, ze względu na stale trwające badania nad jej skutecznością. Wykazano, że osoby otrzymujące najwyższą dawkę tego enzymu odznaczały się najwyższym stopniem redukcji stężenia fenyloalaniny we krwi (RochA i MACDONALD 2016). Terapia ta wydaje się bardzo korzystna, ze względu na wysoka efektywność i długo utrzymujące się obniżone stężenie fenyloalaniny. Jednak u większości osób badanych wystapiły skutki uboczne, tj. bóle głowy, zmęczenie i bóle stawów.

\section{GALAKTOZEMIA}

Galaktoziemia pierwszy raz została opisana w 1917 r. przez Heinricha Gopperta (BROOMFIELD i współaut. 2015), jednak dopiero po kilkudziesięciu latach dowiedziono zwiąku występowania objawów klinicznych choroby $z$ aktywnościa enzymu GALT (urydylotransferazy galaktozo-1-fosforanowej). We wschodniej Europie i Wielkiej Brytanii choroba wystepuje od 1:25 000 do 1:44 000 żywych urodzeń. W Irlandii częstość występowania wynosi 1:16476 żywych urodzeń (Coss i współaut. 2013). Istnieje również wariant tej choroby o łagodniejszym obrazie klinicznym, tzw. Duarte. Wariant Durate występuje ok. 1:4000 w USA (BROOMFIELD i współaut. 2015). Chorzy maja zawsze inne allele tego samego genu, a więc sa heterozygotyczni. Dzięki temu wykazuja o ok. 25\% wyższą aktywność enzymu GALT, w porównaniu do pacjentów $z$ innymi odmianami choroby. 
Przyczyna choroby jest zaburzenie szlaku metabolicznego galaktozy, co może dotyczyć jednego $z$ trzech różnych enzymów. Najpopularniejsza jest postać klasyczna galaktozemii zwiazana $z$ niedoborem enzymu GALT. Najczęstszą mutacją, występująca aż u 65\% chorych, jest zmiana w chromosomie $9 \mathrm{w}$ 13 prążku ramienia krótkiego, powodujacca całkowity brak aktywności enzymatycznej, decydujący o niekorzystnym obrazie klinicznym tej jednostki chorobowej. Enzym GALT odpowiedzialny jest za przekształcenie galaktozo-1-fosforanu i UDP-glukozy w glukozo-1-fosforan oraz UDP-galaktozę. U chorych taka konwersja nie ma miejsca ze względu na prawie zupełny brak aktywności GALT (KERCKHOVE i współaut. 2015). W komórkach gromadzi się galaktozo-1-fosforan i inne metabolity galaktozy, które niszcza hepatocyty oraz elementy morfotyczne krwi, wpływaja na zaburzenia pracy jajników, nerek oraz funkcjonowanie zmysłu wzroku. To właśnie akumulacja tych związków może prowadzić do nasilenia objawów, pomimo stosowania diety o kontrolowanej zawartości galaktozy egzogennej i kontroli metabolicznej.

Pozostałe dwa zaburzenia szlaku metabolicznego zwiazane sa $z$ enzymami: galaktokinaza GALK i epimeraza galaktozo-difosforanową GALE. Wszystkie 3 enzymy: GALK, GALE i GALT, wchodza w skład szlaku Leloira (VAN CALCAR i współaut. 2014b), który umożliwia przekształcanie galaktozy w ufosforylowana glukozę. Jakikolwiek błąd w przebiegu tego szlaku skutkuje gromadzeniem się galaktozy w tkankach, np. wątroby czy nerek. W przypadku braku wczesnej diagnozy u chorych i kontroli stężenia we krwi galaktitolu i galaktonianu, może dojść do uruchomienia alternatywnych szlaków metabolicznych galaktozy. Zwiazane jest to z aktywnościa reduktazy aldozy i reduktazy fosforanu pentozy. Enzymy te biora także udział w kontrolowaniu stężenia UDP-galaktozy, który to zwiazek jest donorem galtitolu w biosyntezie glikoprotein lub glikolipidów. Może więc również nastạpić zaburzenie potranslacyjnej obróbki białek.

Klasyczna galaktozemia jest uważana za ostrą, zagrażająca życiu chorobę. Objawia się głównie zmniejszeniem masy ciała, zaburzeniami funkcjonowania watroby (hepatomegalia), krwawieniami i żółtaczką. Zwiększa się także podatność na zakażenie bakteria Escherichia coli. Konieczne jest leczenie farmakologiczne w celu łagodzenia objawów - podawanie antybiotyków, suplementacja witamina $\mathrm{K}$ i stosowanie dożylnych wlewów płynów. W przypadku mutacji w obrębie genu GALK jedynym objawem wystepujacym u pacjenta jest zaćma, a w wypadku GALE występuje asymptomatyczna hipergalaktozemia (BROOMFIELD i współaut. 2015).

Diagnoza galaktozemii jest utrudniona ze względu na niska specyficzność obrazu klinicznego. U chorych noworodków występuja dysfunkcje wątroby, które moga być mylone $z$ powikłaniami infekcji oraz zaburzeniami budowy tego narządu, np. atrezją dróg żółciowych. Galaktozemia bywa też mylona $z$ innymi wrodzonymi błędami metabolizmu. Ma prawie identyczny obraz kliniczny jak tyrozynemia typu I (Bosch 2011).

W celu zdiagnozowania tej choroby stosuje się badanie określające aktywność enzymu GAL-1-PUT (GALT) przez fluorescencyjny test punktowy Beutlera oraz oznaczenie ilościowe GALT w erytrocytach (BROOMFIELD i współaut. 2015). W teście Beutlera, aktywność enzymu GALT monitoruje się $z$ użyciem fosfoglukomutazy i dehydrogenazy glukozo-6-fosforanu oraz obserwuje się zjawisko fluorescencji zredukowanego NADP+ w świetle ultrafioletowym (FUJIMOTO i współaut. 2000). Test potwierdza chorobę, jeśli plama krwi nie fluoryzuje w świetle UV. Sa to metody pracochłonne, ale dajace możliwość postawienia prawidłowej diagnozy.

\section{LECZENIE DIETETYCZNE}

Leczenie dietetyczne galaktozemii rozpoczyna się od razu po diagnozie, ze względu na możliwe znaczne zaburzenia neurologiczne, pojawiające się już w pierwszym miesiącu życia. Podstawowym założeniem leczenia dietetycznego jest eliminacja galaktozy egzogennej. W organizmie dorosłego człowieka syntetyzowane jest naturalnie więcej niż $1000 \mathrm{mg}$ galaktozy na dobę. Oznacza to, iż nie jest możliwa dokładna kontrola stężenia galaktozy, ponieważ endogenna synteza może być zmienna.

Żywienie noworodka rozpoczyna się od wprowadzenia preparatów mlekozastępczych, bazujacych na soi, np. Isomil. Dostępne sa one w formie płynu lub proszku. Proszek nie zawiera laktozy i ma znacznie mniej galaktozy, ze względu na to, iż w formie płynnej używany jest karagenian jako emulsyfikator. Gdy odmiana choroby jest łagodna, można podawać dziecku preparaty mlekozastępcze bazujace na hydrolizatach kazeiny, ale sa one znacznie bogatsze w galaktozę. Wyjątek stanowią wcześniaki, którym bezwzględnie nie można podawać preparatów sojowych. W badaniach klinicznych wykazano, że u wcześniaków karmionych preparatami sojowymi stwierdza się obniżone stężenie fosforu i podwyższone stężenie fosfatazy alkalicznej, w porównaniu do grupy kontrolnej karmionej mlekiem matki, co może prowadzić w przyszłości do wystapienia osteopenii. Istnieja również doniesienia, ze preparaty sojowe 
stosowane od pierwszych dni życia moga wpłynać negatywnie na płodność w dorosłym życiu (VAN CALCAR i współaut. 2014b).

Po okresie niemowlęctwa obowiazuje bezwzględna eliminacja mleka krowiego i innych produktów mlecznych $z$ wysoka zawartościa białka i laktozy (Bosch 2011). Należy jednak zapewnić dziecku roślinne lub bezlaktozowe zamienniki tych produktów.

Wraz $z$ wiekiem chorego można zaobserwować wzrost tolerancji galaktozy. $Z$ tego powodu obecne zalecenia wskazuja, iż po 14. roku życia do diety chorego można podejść mniej restrykcyjnie. Przez całe życie dieta powinna być pozbawiona laktozy, ale bez ograniczeń moga być spożywane owoce i warzywa. Nie zaleca się jednak niekontrolowanego ich spożycia w żywieniu dzieci poniżej 14 roku życia, gdyż wnosza one dodatkowe ilości galaktozy, co może utrudniać ustabilizowanie przebiegu choroby. Od 1. roku życia dziecka dietę należy wzbogacać w umiarkowanych ilościach w napoje sojowe i soki owocowe fortyfikowane wapniem. Zaleca się również suplementację witamina D i wapniem, ze względu na obniżona gęstość kośćca u wielu chorych, spowodowana restrykcjami w wyborze produktów w diecie eliminacyjnej. Od momentu rozpoczęcia rozszerzania diety do wieku ok.12 lat stężenie galaktitolu w moczu należy kontrolować co 3-4 miesiace, natomiast po przekroczeniu 12 lat wykonywać je raz do roku (BROOMFIELD i współaut. 2015). W Polsce kontrola przebiegu choroby wygląda podobnie do założeń opisanych przez Broomfielda. Do 1 roku życia wizyty kontrolne odbywaja się co 3 miesiace, do 4 roku życia - co 4 miesiace, do 12 - co pół roku i po 12 roku życia - raz w roku. Jeśli pojawiają się problemy ze stosowaniem diety czy niepokojace objawy dotyczace zdrowia pomiędzy wizytami, częstotliwość ich należy dostosowywać do sytuacji. Ocenie podlega głównie rozwój fizyczny dziecka i sposób jego żywienia, ze szczególnym zwróceniem uwagi na odpowiednia podaż wapnia. Dodatkowo oznaczane jest stężenie galaktozo-1-fosforanu we krwi. Parametr ten powinien wynosić max. $3 \mathrm{mg} / \mathrm{dl}$, co jest dowodem prawidłowo prowadzonej diety (RADOMYSKA 2013).

Główną grupa produktów podlegajaca eliminacji $z$ diety takich chorych jest nabiał, ze szczególnym uwzględnieniem jogurtów i serków wiejskich $z$ mleka krowiego, zawierajacych największe ilości galaktozy (ok. $2400 \mathrm{mg} / 100 \mathrm{ml}$ ). W przypadku serów dojrzewających na stężenie galaktozy wpływa wiele czynników: rodzaj kultury starterowej, temperatura dojrzewania i jakość mleka. Bezpiecznymi do spożycia serami sa tylko: Gruyere, Parmezan (dojrzewajacy dłużej niż
10 lat) i Emmentaler (tylko produkowany w Europie i Północnej Ameryce) (VAN CALCAR i współaut. 2014a).

W Wielkiej Brytanii przeprowadzono badania dotyczące podaży galaktozy egzogennej, czyli przyjmowanej z pożywieniem. Wyniki wskazywały, iż nie ma żadnych przesłanek, by u chorych $z$ dieta bezlaktozowa dodatkowo ograniczać podaż owoców. W jednej grupie badani spożywali dietę bezlaktozową $\mathrm{z}$ ograniczona podażą owoców, gdzie podaż galaktozy wynosiła ok. $30 \mathrm{mg} / 24 \mathrm{~h}$. Natomiast w drugiej grupie, chorzy spożywali dietę bezlaktozowa wzbogacana owocami, gdzie podaż galaktozy wynosiła max. $54 \mathrm{mg} / 24 \mathrm{~h}$ (BoscH 2011). We krwi obu grup nie wykryto różnic w stężeniach galaktozo-1-fosforanu. Stwierdzono więc, że nie ma podstaw do unikania i eliminowania owoców w diecie chorego. Ważne jest jednak, by spożywane owoce i warzywa charakteryzował niższy stopień dojrzałości, ponieważ podczas dojrzewania rośliny produkuja galaktozydazę, która uwalnia wolna galaktozę, co naturalnie zwiększa jej stężenie. Korzystniej jest także podawać choremu warzywa i owoce w formie surowej, ze względu na wzrastajace stężenie galaktozy w miare trwania obróbki termicznej.

Sporną grupa produktów w przebiegu dietoterapii tej choroby sa rośliny straczkowe. W badaniach z 2014 r. podzielono chorych na 3 grupy: spożywajacych przez 3 tygodnie produkty będące źródłem wolnej galaktozy (warzywa i owoce), spożywajacych czystą rafinozę lub stachiozę (rośliny stracczkowe) i niespożywających żadnych roślin stracczkowych. Wykazano, że nie ma żadnych różnic między grupami w stężeniu galaktozo-1-fosforanu w erytrocytach ani w poziomie wydalania galaktitolu $z$ moczem (VAN CALCAR i współaut. 2014b). Fermentowane produkty sojowe, tj. tempeh, sufu, miso, natto, oraz sos sojowy zawieraja znacznie wyższe stężenia galaktozy, ponieważ fermentacja powoduje uwolnienie jej $z$ oligosacharydów. $Z$ tej samej przyczyny $z$ diety wykluczana jest także fasola garbanzo.

\section{CHOROBY SPICHRZENIOWE GLIKOGENU}

Glikogenozy (GSD) to grupa chorób wynikajacych $\mathrm{z}$ zaburzonego funkcjonowania enzymu syntetyzujaccego lub degradujacego glikogen. Istnieja postacie choroby, takie jak glikogenozy watrobowe i nerwowo-mięśniowe.

W 1936 r. Carl i Gerti Cori zidentyfikowali po raz pierwszy glukozo-1-fosforan (znany także jako ester Cori), dzięki czemu odkryli podłoże biochemiczne glikogenozy typu I, inaczej zwanej choroba von Gierkego (BHATTACHARYA i współaut. 2016). Choroba 
ta objawiała się głównie zaburzeniami psychosomatycznymi i hepatomegalia u dzieci. W latach 60. XX w. Henri Gery Hers zidentyfikowal podstawy enzymatyczne glikogenozy typu II. W nastepnych latach opisane zostały kolejne postacie choroby.

Glikogenozy moga mieć różny przebieg. Niektóre $z$ nich moga być śmiertelne już w okresie niemowlęctwa, inne stanowią łagodniejsza postać choroby i przy odpowiednim podejściu żywieniowym nie muszą obniżyć jakości życia chorego. Zależnie od typu choroby zmienia się obraz kliniczny. Glikogenozy moga powodować uszkodzenie pojedynczych tkanek i narzaców, np. watroby lub nerek, lub zaburzaja pracę całych układów w organizmie.

Diagnoza choroby opiera się na wynikach badań histopatologicznych, głównie mięśni i watroby pobranych podczas biopsji, w połaczeniu $z$ mikroskopia elektronowa oraz na badaniach biochemicznych. Zależnie od typu glikogenozy, niedobór lub całkowity brak enzymów można wykryć także w skórnych fibroblastach (CHEN i WEINSTEIN 2016). W ciagu ostatnich 10 lat „złotym standardem” diagnostyki jest molekularna analiza DNA.

Objawy glikogenoz sa zależne od miejsca, w którym odkłada się glikogen W przypadku kumulacji glikogenu w watrobie, występuje hipoglikemia, hepatomegalia, liczne dyslipidemie i kwasica mleczanowa (RAKE i współaut. 2002). Gdy glikogen odkłada się w tkance mięśniowej, pojawia się hipotonia, bóle i osłabienie mięśni oraz mioglobinuria. Nie pojawia się natomiast hipoglikemia, co umożliwia odróżnienie obu głównych typów choroby.

Istnieje wiele typów chorób spichrzeniowych glikogenu. Zmiany chorobowe pojawiaja się w narzadach, w których dochodzi do odkładania się glikogenu. W typie Ia i Ib zmiany występuja w nerkach, a w typie II w neuronach i mięśniu sercowym. Do akumulacji glikogenu w erytrocytach zachodzi w typie VII, natomiast w typie IX, którego dziedziczenie jest sprzężone $z$ chromosomem $\mathrm{X}$, akumulacja ma miejsce w mózgu.

Specyficzna odmiana choroby jest grupa ketogenicznych form glikogenoz. Dotyczy ona typu III, VI i IX. W tych wypadkach oksydacja tłuszczu nie zostaje zahamowana, co prowadzi do nadmiernego powstawania ketonów, przy równoczesnym wystąpieniu hipoglikemii. U chorych obserwuje się znaczne podwyższenie stężenia mleczanu po posiłku. Powodem jest uruchomienie alternatywnych szlaków metabolizowania wolnej glukozy, co prowadzi do degradacji struktury wattroby. Natomiast wydzielanie insuliny nadal pozostaje na stałym poziomie (BHATTACHARYA i współaut. 2016).

\section{LECZENIE DIETETYCZNE}

Dietoterapia w chorobach spichrzeniowych glikogenu głównie ma na celu utrzymanie normoglikemii, gdyż stany hipoglikemii stanowią największe zagrożenie dla zdrowia chorego. Hipoglikemia występujacca $u$ chorych ma charakter ketotyczny, co oznacza, iż jej epizody sa wywoływane tylko długotrwałym ograniczeniem spożycia pożywienia lub infekcja. Zagraża to życiu pacjenta i może grozić zaburzeniami neurologicznymi, m.in. problemami ze skupieniem, trudnościami w mowie czy zaburzona koordynacja ruchowa, czyli stanem neuroglikopenii (HENDRIKSZ i GISSEN 2010).

Każdy typ glikogenozy wymaga innych zaleceń dotyczacych dietoterapii. Jednak, niezależnie od typu choroby, konieczne jest ograniczenie spożycia tłuszczów zwierzęcych i węglowodanów prostych. Ważna jest także eliminacja produktów słodzonych sorbitolem, czyli np. gum do żucia czy napojów typu light. Sorbitol jest zredukowana postacia glukozy i prekursorem glikogenu watrobowego. Eliminacja sorbitolu $z$ diety ogranicza magazynowanie niewykorzystanej glukozy w formie glikogenu watrobowego. Taka restrykcja jest również korzystna ze względu na zminimalizowanie znaczacych zmian stężeń glukozy we krwi i normalizację stężenia kwasu mlekowego (EMCZYŃSKA-SELIGA 2016). W chorobach spichrzeniowych glikogenu kontroli wymaga także stężenie cholesterolu i triacylogliceroli.

Celem leczenia dietetycznego glikogenozy typu I jest limitowanie endogennej produkcji glukozy. Należy więc zapewnić choremu odpowiednia jej podaż, by zapobiec wystąpieniu hipoglikemii. W tym celu stosuje się strategie żywieniowe takie jak: czeste podawanie posiłków $z$ dodatkiem ugotowanej skrobi kukurydzianej, podawanie samej nieugotowanej skrobi kukurydzianej lub ciagłe nocne karmienie przez sondę. Zapotrzebowanie na glukozę zmniejsza się wraz $z$ wiekiem pacjenta i obliczane jest na podstawie teoretycznej produkcji glukozy. W przypadku wystapienia ostrego stanu hipoglikemii, wymagającego natychmiastowej kompensacji, roztwór glukozy podawany jest dożylnie w bolusie (pojęcie określajace podanie leku w dużej dawce, majace na celu uzyskanie efektywnego stężenia w tkankach w jak najkrótszym czasie) w ciagu 10 minut, a następnie, zależnie od temperatury ciała, $125-150 \%$ zapotrzebowania na glukozę przez kolejne 12 godzin (RAKE i współaut. 2002). Konieczna jest eliminacja $z$ diety fruktozy i galaktozy, ponieważ sa one metabolizowane do glukozo-6-fosforanu. Nadmiar glukozo-6-fosforanu nie jest pożądany, ze względu na fakt, iż w GSD I nie zachodzi w pełni przekształcenie 
glukozo-6-fosforanu do glukozy. Zalecane jest wdrożenie diety wysokowęglowodanowej (nawet do 70\% energii $z$ węglowodanów), przy $10-15 \%$ podaży energii $z$ białka.

Dziecko może być od urodzenia karmione piersią. Dozwolona jest również podaż wysokowęglowodanowych mieszanek mlekozastepczych, pozbawionych galaktozy i fruktozy. W trakcie 4-6 miesiacca życia rozszerza się dietę dziecka, podając mu np. ryż czy kaszki i płatki przeznaczone dla niemowlat. Tego rodzaju produkty powinny dostarczać złożonych węglowodanów, które sa skuteczniejsze w utrzymywaniu normoglikemii. W kolejnych miesiaccach czy latach życia dziecka płatki owsiane, ryż, makarony i nasiona roślin straczkowych są bardziej polecane w diecie niż ziemniaki i pszenne pieczywo, $z$ uwagi na niższy indeks glikemiczny.

W miarę rozwoju dziecka do diety można w ograniczonych ilościach włączać owoce oraz mleko i produkty mleczne, ale obserwować reakcje organizmu oraz kontrolować podstawowe parametry świadczace o nadmiernej podaży galaktozy. $Z$ diety, niezależnie od wieku, należy całkowicie wyeliminować suszone owoce, daktyle i słodzone płatki śniadaniowe. Zapotrzebowanie na tłuszcz powinno być pokryte przez podaż olejów roślinnych i margaryn bogatych $\mathrm{w}$ wielonienasycone kwasy tłuszczowe.

Leczenie dietetyczne tego typu glikogenozy wspomaga się również dwiema dodatkowymi strategiami żywieniowymi. Zauważalne korzyści przynosi nocne żywienie niemowląt przez sondę (ang. overnight gastric feeding, OGF), mieszankami pozbawionymi laktozy i sacharozy. Ułatwia to utrzymanie normoglikemii, niezależnie od rozkładu posiłków w ciagu doby. Wspomaganie dietoterapii powinno rozpoczaćc się w szpitalu, pod ścisła kontrolą lekarza, od $7 \mathrm{mg}$ glukozy/kg m.c./ minutę. Po wyznaczonym okresie należy ta ilość zredukować do 4-6 mg/kg m.c/minutę (GoldBerG i SLONIM 1993).

Kolejna forma terapii jest suplementacja skrobia kukurydziana (ang. uncooked cornstarch supplementation, UCS). Skrobia metabolizowana jest znacznie wolniej niż glukoza, dzięki czemu możliwe jest utrzymanie odpowiedniej glikemii. UCS jest dodatkiem do zwyczajowego żywienia oraz uzupełnieniem OGF, do momentu normalizacji stężeń glukozy. Metoda ta nie jest jednak rekomendowana dzieciom poniżej 2 roku życia, ze względu na niedostatecznie rozwinięta aktywność ich amylazy trzustkowej (GOLDBERG i SLONIM 1993).

Dietoterapia w typie III glikogenozy budzi najwięcej kontrowersji wśród dietetyków i lekarzy. Większość zaleca dietę analogiczną do typu I, jednak bez eliminacji mleka i owo- ców. Pozostali zalecają dietę wysokowęglowodanowa, ze względu na większą efektywność w osiaganiu normoglikemii. Przy stosowaniu takiej diety nie zauważa się jednak znaczącej poprawy wyników, biorąc pod uwage hepatomegalię, osłabienie siły mięśniowej i zaburzenia rozwoju, co można zaobserwować przy stosowaniu diety wysokobiałkowej (KISHNANi i współaut. 2010). Dietę dzieci chorych na GSD III należy dodatkowo suplementować żółtkiem jaja, mięsem drobiowym i nabiałem (DAGLI i współaut. 2009b). Po skończeniu 1. roku życia codzienna podaż specjalnej odżywki należy zamienić na niskotłuszczowe mleko. Należy również ograniczyć ilość tłuszczu zwierzęcego, na korzyść tłuszczów roślinnych, ze szczególnym uwzględnieniem produktów takich jak: ryby, orzechy i oleje roślinne, obfitujace w wielonienasycone kwasy tłuszczowe.

W przypadku glikogenozy typu VI zalecana jest również dieta wysokobiałkowa $i$ zwiększona częstotliwość karmienia dziecka. Po nocnej przerwie możliwe jest pojawienie się wymiotów rano. Wynika to $z$ faktu, iż wskutek kilkugodzinnego ograniczenia przyjmowania pokarmów, znaczaco spada stężenie glukozy we krwi i dochodzi do stanu hipoglikemii o charakterze ketotycznym. Jej typowym objawem sa właśnie nudności i wymioty. By tego uniknąć należy budzić dziecko w nocy lub wcześnie rano i podać mu wysokobiałkowa przekąskę.

W glikogenozie typu IX zarówno dieta wysokobiałkowa, jak i dieta wysokowęlowodanowa przynosza porównywalne korzyści. Parametrem umożliwiającym ocenę efektywności stosowanej diety jest pomiar wielkości watroby w obrazie ultrasonograficznym. Przy prawidłowej dietoterapii, powiększona wcześniej wątroba zmniejsza się do prawidłowego rozmiaru (KARANDE i współaut. 2016).

Typ IV glikogenozy nie jest podatny na leczenie dietetyczne. W tym wypadku zalecana jest jak najwcześniejsza transplantacja watroby. Jednak pojawiały się badania sugerujace, iż dieta bogata w białko i jednocześnie uboga w węglowodany, może wspomóc proces leczenia również tego typu glikogenozy (GOLDBERG i SLONIM 1993). Ta odmiana choroby uważana jest za najrzadsza $(0,3 \%$ wszystkich zachorowań na choroby spichrzeniowe glikogenu), a chorzy nie dożywaja zwykle 5. roku życia.

\section{PODSUMOWANIE}

Leczenie dietetyczne fenyloketonurii, galaktozemii i chorób spichrzeniowych glikogenu jest skomplikowane i wymaga wysokiego stopnia indywidualizacji, lecz przynosi pacjentom zauważalne korzyści. Postępy w 
zakresie dietetyki i medycyny pozwalaja na coraz szybsze diagnozowanie i skuteczniejsze leczenie chorych $\mathrm{z}$ wrodzonymi genetycznie uwarunkowanymi chorobami metabolicznymi. Należy pamiętać, że sa to choroby nieuleczalne, a cały proces leczenia ukierunkowany jest głównie na łagodzenie objawów choroby i, przede wszystkim, podnoszenie jakości życia chorego oraz jego rodziny.

\section{Streszczenie}

Wrodzone zaburzenie metabolizmu to grupa chorób genetycznych, których podłożem jest upośledzenie określonego szlaku metabolicznego. Fenyloketonuria to enzymopatia polegajaca na defekcie genu kodujacego hydroksylazę fenyloalaninowa, czego konsekwencja sa przede wszystkim zaburzenia neurologiczne. Dzięki wczesnemu wdrożeniu odpowiedniej dietoterapii można prawie całkowicie ograniczyć te dysfunkcje. Klasyczna galaktozemia spowodowana jest deficytem aktywności enzymu urydylotransferazy galaktozo-1-fosforanowej GALT, w wyniku czego dochodzi do zaburzenia szlaku przemian galaktozy. Leczenie dietetyczne opiera się głównie na spożywaniu produktów o niskiej zawartości galaktozy i eliminacji laktozy, bez konieczności wykluczania $z$ diety owoców warzyw. Glikogenozy to grupa zaburzeń wynikających $z$ defektu specyficznego dla odmiany choroby, enzymu niezbędnego do degradacji lub syntezy glikogenu. Istnieja strategie dietetyczne ułatwiające leczenie, jak OGF (nocne karmienie) lub UCS (suplementacja skrobia kukurydziana). Dietoterapia chorych $z$ genetycznymi zaburzeniami metabolizmu jest wysoce zindywidualizowane. W większości przypadków przynosi spodziewane efekty i podnosi komfort życia chorych.

\section{LITERATURA}

Argmann C., Houten S., ZHU J., SchadT E. 2016. A next generation of multiscale view of inborn errors of metabolism. Cell Metab. 23, 13-26.

El-HATTAB A., REID SUTTON V., 2012. Inborn errors of metabolism. [W:] Manual of neonatal care. ClOHERTY J. P., EICHENWAld E. C., HANSEN A. R., STARK A. R. (red.). Philadelphia: Lipincott Williams and Wilkins, 767-790.

BHATTACHARYA K., PONTIN J., THOMPSON S., 2016. Dietary management of the Ketogenic Glycogen Storage Diseases. J. Inborn Errors Metab. Screen. 4, 1-6.

BiK-Multanowski M., PietrzyK J., 2009. Genotypowanie a zmiana rodzaju leczenia u pacjentów $z$ fenyloketonuria jako wstep do farmakogenomiki. Przegl. Lek. 66, 1-3.

Bosch A., 2011. Classic galactosemia: Dietary di lemmas. J. Inherit. Metab. Dis. 34, 257-260.

BROOMFIELD A., BRAIN C., GRUNEWALD S., 2015. Galactosaemia: diagnosis, management and long - treatment outcome. Paediatr. Child Health 25, 113-118.

CHEN M., WeINSTEIN D., 2016. Glycogen storage diseases diagnosis, treatment and outcome. Translat. Sci. Rare Dis. 1, 45-72.

CONCOLINO D., MASCARO I., MORICCA1 M., BONAPACE G., Matalon K., TRAPasso J., RADHAKRISHNAN G., FERRARA C., MATALON R., STRISCIUGLIO P., 2017. Long-term treatment of phenylketonuria with a new medical food containing large neutral amino acids. Eur. J. Clin. Nutrit. 71, 51-55.
Coss K. P., Doran P. P., OWOEye C., CodD M. B., HAMID N., MAYNe P. D., CRUShell E., KNERR I., MONAVARI A. A., TREACY E. P., 2013 Classical galactosemia in Ireland: incidence, complicationand outcomes of treatment. J. Inherit. Metab. Dis. 36, 21-27.

Dagli A., Zori R., HeEse B., 2009a. Postepowanie diagnostyczne we wrodzonych wadach metabolicznych u noworodków. Pediatria po Dyplomie 13, 62-76.

Dagli A., Zori RT., Mccune H., Ivsic T., MaisenBACHER M. K., Weinstein D. A., 2009b. Reversal of glycogen storage disease type IIIa - related cardiomyopathy with modification of diet. J. Inherit. Metab. Dis. 32, 103-106.

EMCZYŃSKA-SELIGA E., 2016. Leczenie dietetyczne $w$ chorobach spichrzania glikogenu. Współczesna Dietetyka 4.

FUJimoto A., OKANO Y., MiYagi T., Isshiki G., OURA T., 2000. Quantitative Beutler Test for newborn mass screening of galactosemia using a fluorometric microplate reader. Clin. Chem. 46, 806-810.

GARROD A. E, OXON M. D., LOND F. R. C. P., 1902. The incidence of alkaptonuria: a study in chemical individuality. Lancet 160, 16161620.

Geiger K., Koeller D., Harding C., Huntigton K., GiLligham M., 2016. Normal vitamin D levels and bone mineral density among children with inborn errors of metabolism consuming medical food - based diets. Nutrit. Res. 36, 101-108.

GOLDBERG T., SLONIM A., 1993. Nutrition therapy for hepatic glycogen storage diseases. J. Am. Dietet. Assoc. 93, 1423-1430.

HENDRIKSZ C., Gissen P., 2010. Glycogen storage disease. Paediatr. Child Health 21, 84-89.

JAROCHOWICZ S., MAZUR A., 2007. Fenyloketonuria - choroba metaboliczna uwarunkowana genetycznie. Przegląd Medyczny Uniwersytetu Rzeszowskiego 1, 76-90.

JEANMONOD R., ASUKA E., JEANMONOD D., 2020. Inborn errors of metabolism. StatPearls Publishing.

KARANDE I., Boulter E., QueIT L., BALASubramaNIAM S., 2016. Structured dietary management dramatically improves marked transaminitis, metabolic and clinical profiles in glycogen storage disease type IXa. J. Inborn Errors Metab. Screen. 4, 1-4.

Kerckhove K., Diels M., Vanhaesebrouck S., LUYTEN K., PYCK N., DE MEYER A., VAN DRIESSCHE M., ROBERT M., CORTHOUTS K., CARIS A, Duchateau E., DASSY M., BIHET G., 2015. Consensus on the guidelines for the dietary management of classical galactosemia. Clin. Nutrit. ESPEN 10, 1-4.

Kishnani P., AUSTIN S., ARN P., BALI D., BONEY A., CASE L., Chung W., Desai D., El-GharBawy A., Haller R., SMit P., SMith A., HobSON-WEB L., WECHSLER S., WEINSTEIN D., WATSON M., 2010. Glycogen storage disease type III diagnosis and management guidelines. Genet. Med. 12, 446-463.

MAZURCZAK T., ŻEKANOWSKI C., NOWACKA M., BAL J., 2000. Zasady diagnostyki molekularnej dziedzicznej hiperfenyloalaninemii. Ekspertyza naukowa wykonana dla Ministerstwa Zdrowia.

OŁTARZEWSKI M., 2018. Badania przesiewowe noworodków $w$ Polsce 2018 rok. Post. Neonatol. 24, 111-122.

Pena M., Almeida M., VAN DAM E., Ahring K., BÉlANGER-QUINTANA A., DOKOUPIL K., GOKMEN-OZEL H., LAMMARDo A., MACDONALD A., 
RochA M., RoBert M., RochA J., 2015. Special low protein food for phenyloketonuria: availability in Europe and examination of their nutritonal profile. Orphanet J. Rare Dis. 10, doi: 10.1186/s13023-015-0378-7.

RADOMYSKA B., 2013. Diagnostyka i opieka nad chorymi z klasyczna galaktozemia. www.standardy.pl/pediatria.

RochA J., MACDONALD A., 2016. Dietary intervention in the management of phenylketonuria: current perspectives. Pediatr. Health Med. Therapeut. 7, 155-163.

Singh R., Rohr F., Frazier D., Cunningham A., Mofidi S., OGata B., Splett P., MOSEley K., HUNTINGTON K., ACOSTA P., VOCKLEY J., VAN CALCAR S., 2014. Recommendation for the nutrition management of phenyalanine hydroxylase deficiency. Genet. Med. 16, 121-131.

RAKE J., VISSER G., LABRUNE P., LEONARD J., UlLRICH K., SMIT P., 2002. Guidelines for management of glycogen storage disease type I - European Study on Glycogen Storage Disease Type I (ESGSD I). Eur. J. Pediatr. 161, 112-119.

VAN CALCAR S., BERnstein L., ROHR F., YANNICELLI S., BERRY G., SCAMAN C., 2014a. Galactose content of legumes, caseinates and some hard cheeses: implications for diet treatment of classic galactosemia. J. Agric. Food Chem. 62, 1397-1402.

VAN CAlCAR S., Bernstein L., ROHR F., YANNICELli S., BERRY G., SCAMAN C., 2014b. A re-evaluation of life-long severe galactose restriction for the nutrtion management of classic galactosemia. Mol. Genet. Metab. 112, 191-197.

VAN Vliet D., VAN DER GOOT E., VAN GINKEL W., Van FaAssen M., De BlaAuw P., Kema I., MARTINEZ A., HEINER-FOKKEMA R., VAN DER ZEE E., VAN SPRONSEN F., 2019. The benefit of large neutral amino acid supplementation to a liberalized phenylalanine-restricted diet in adult phenylketonuria patients: evidence from adult Pah-Enu2 mice. Nutrients 11, doi: 10.3390/nu11092252.

YILDIZ Y., SIVRI H. S., 2019 Maternal phenylketonuria in Turkey: outcomes of 71 pregnancies and issues in management. Eur. J. Pediatr. 178, 1005-1011.

ŻóŁKOWSKa J., HozYASZ K. K., NOWACKA M., 2018 Zapobieganie zespołowi fenyloketonurii matczynej, czyli leczenie dietetyczne fenyloketonurii $w$ okresie prekoncepcyjnym $i w$ czasie cia$\dot{z} y$. Pediatria i Medycyna Rodzinna 14, 47-53.

KOSMOS Vol. 69, 2, 323-331, 2020

JoAnna Pieczyńska, Karolina Łagowska

Institute of Human Nutrition and Dietetics, Poznan University of Life Sciences, 31 Wojska Polskiego Str., 60-624 Poznań, E-mail: joanna.pieczynska@onet.eu, karolina.lagowska@up.poznan.pl

RARE METABOLIC DISEASES - CHARACTERISTIC AND DIETARY TREATMENT

\section{Summary}

Congenital metabolism disorder is a group of genetic diseases that are caused by impairment of a specific metabolic pathway. Phenylketonuria is an enzymopathy involving a defect in the gene coding for phenylalanine hydroxylase, the consequence of which are primarily neurological disorders. Thanks to the early implementation of appropriate dietotherapy, these dysfunctions can be almost completely reduced. Classical galactosemia is caused by a deficit in the activity of the galactose-1-phosphate galactose uridine transferase enzyme GALT, resulting in a disruption of the galactose pathway. Dietary treatment is mainly based on eating low-galactose products and eliminating lactose, without having to exclude fruits and vegetables from the diet. Glycogenosis is a group of disorders resulting from a disease-specific defect, an enzyme necessary for glycogen degradation or synthesis. There are dietary strategies to facilitate treatment, such as OGF (overnight gastric feeding) or UCS (uncocked corn starch supplementation). Diet therapy for patients with genetic metabolism disorders is highly individualized. In most cases, it brings the expected results and increases the quality of life of patients.

Key words: galactosemia, glycogenosis, inborn errors of metabolism, phenylketonuria 